\title{
Upregulated Hoxc6 expression is associated with poor survival in gastric cancer patients
}

\author{
Q. ZHANG, X. S. JIN, Z. Y. YANG, M. WEI, B. Y. LIU*, Q. L. GU*
}

Department of General Surgery, Shanghai Institute of Digestive Surgery, Ruijin Hospital, Shanghai Jiao Tong University School of Medicine, Shanghai, China 197 Ruijin Er Road,Shanghai 200025, China

*Correspondence: qlgu@shsmu.edu.cn,liubyrj@yahoo.com.cn

Received September 25, 2012/ Accepted January 21, 2013

\begin{abstract}
Human Hox genes (Homeobox) have crucial roles in development and differentiation, regulating numerous processes including apoptosis, receptor signalling, differentiation, motility and angiogenesis. Aberrant expression of Hoxc6 gene has been reported in several tumor tissues and cancer cell lines. The prognostic significance of Hoxc6 in gastric cancer remains largely unknown. This study was aimed to investigate the clinical significance of Hoxc6 in gastric cancer.

Total RNA of paired tissue samples $(n=25)$ and a tissue microarray containing 161 paired tissues from patients with gastric cancers at different stages were collected. Quantitative real-time PCR and immunochemistry assay were carried out to investigate the expression of Hoxc6.

Hoxc6 mRNA was increased in gastric cancer tissues ( 16 of 25) compared with the adjacent normal mucosa $(\mathrm{P}<0.05)$. Immunohistochemical detection showed that expression of Hoxc6 was associated with the depth of tumor invasion $(\mathrm{P}<0.05)$. Patients with higher expression levels of Hoxc6 had a shorter overall survival rate $(\mathrm{P}<0.05)$.

Hoxc6 might contribute to the progression of gastric carcinogenesis and may be a significant predictor of poor survival in patients with gastric cancer after curative operations.
\end{abstract}

Key words: gastric cancer, Hoxc6 gene, tissue microarray, prognostic marker

There are 4 clusters of Hox genes (HOXA, HOXB, HOXC, and HOXD) in humans that are localized on chromosomes 2, 7,12 , and 17. Homeobox (HOX)genes are a family of at least 200 transcription factors and contain a highly conserved 61 amino-acid homeodomain that binds specifically to DNA. Hox family genes play key roles in development and differentiation regulating numerous processes including apoptosis, receptor signalling, differentiation, motility and angiogenesis. with some Hox genes expressed in the embryo, and others expressed in fully differentiated tissues [1].

Abnormal Hox gene expression has been found in cancers such as leukemia [2], colorectal cancer [3], breast cancer [4], renal cancer [5], melanoma [6], and skin squamous cancer [7]. The pathways by which Hox genes exert their effects are notably varied, with distinct tissue specificity. In some cancers, such as leukemias, fusion protein-mediated over expression of certain Hox genes induces clonal expansion [8)] in others, such as neuroblastoma, expression of even a single Hox gene promotes differentiation and prevents tumorigenesis [9]. In some tumors, aberrant Hox gene expressions directly drives tumorigenesis through escape from apoptosis [10], alterations to receptor signalling [11], tumor cell invasion [12], and epithelial-mesenchymal transition (EMT) [13].

Hoxc6 that is localized on chromosomes 12q13.3 shares a 5 ' non-coding exon with Hoxc5 and Hoxc4, upregulation of Hoxc6 has been reported in some tumors, such as osteosarcoma [14], neuroblastoma [15], breast cancer [16], lung cancer [17] and prostate cancer [18].

Gastric cancer is one of the most common malignant tumors and the second leading cause of cancer mortality worldwide. Although the decline in the incidence during the past decade, gastric cancer remains a major health problem because of the slow incidence decline in Asia and high mortality in the west [19-21]. Gastric cancer is usually detected at an advanced stage in many patients with lymph node invasion and metastasis. Despite a curative operation and postoperative adjuvant therapy, nearly $60 \%$ of those patients die of this fatal disease [22-24]. The total prognosis of gastric cancer is still 
poor [25]. Currently, the tumor $(\mathrm{T})$ node $(\mathrm{N})$ metastasis $(\mathrm{M})$ stage is still the most important prognostic factor for gastric cancer. Prognosis often varies among patients in the same stage [26]. Therefore, identification of reliable molecular targets in chemotherapy of gastric cancer is very important [27 ].

There has not been reported whether or not Hoxc6 gene is aberrantly expressed in gastric epithelial neoplasms. The present study examined Hoxc6 mRNA and protein expressions in gastric cancer specimens and evaluated clinicopathological significance and prognostic value of Hoxc6 expression in gastric cancer patients to determine the possible use of Hoxc6 as a prognostic molecular marker in gastric cancer.

\section{Materials and methods}

Patients and tissue samples. This study was approved by the Research Ethics Committee of Ruijin Hospital, Shanghai Jiao Tong University School of Medicine. China. Written informed consent was obtained from all of the patients enrolled in this study. All specimens were handled and made anonymous according to the ethical and legal standards.

Tissue specimens for Quantitative real-time PCR. Fresh specimens for real-time quantitative reverse transcriptionpolymerase chain reaction( qRT- PCR ) were obtained from

Table 1. Characteristics of patients with gastric cancer

\begin{tabular}{|c|c|c|}
\hline Factor & No. & $\%$ \\
\hline \multicolumn{3}{|l|}{ Gender } \\
\hline Male & 17 & 68 \\
\hline Female & 8 & 32 \\
\hline \multicolumn{3}{|l|}{ Age (years old) } \\
\hline$\leqq 60$ & 9 & 36 \\
\hline$>60$ & 16 & 64 \\
\hline \multicolumn{3}{|l|}{ Differentiation } \\
\hline Poor & 19 & 76 \\
\hline Well+Intermediate & 6 & 24 \\
\hline \multicolumn{3}{|l|}{ Tumor Site } \\
\hline Pylorus & 15 & 60 \\
\hline Gastric Corpus & 7 & 28 \\
\hline Gastric Fundus & 3 & 12 \\
\hline \multicolumn{3}{|c|}{ Tumor Size (in Diameter) } \\
\hline$\leqq 5 \mathrm{~cm}$ & 13 & 52 \\
\hline$>5 \mathrm{~cm}$ & 12 & 48 \\
\hline \multicolumn{3}{|l|}{ Depth of Invasion } \\
\hline Mucosa & 5 & 20 \\
\hline Muscular Layer & 9 & 36 \\
\hline Serosa & 11 & 44 \\
\hline \multicolumn{3}{|l|}{ Lymph Node Status } \\
\hline N0 & 9 & 36 \\
\hline N1-3 & 16 & 64 \\
\hline \multicolumn{3}{|l|}{ p-Stage } \\
\hline $\mathrm{I}+\mathrm{II}$ & 13 & 52 \\
\hline III+IV & 12 & 48 \\
\hline
\end{tabular}

25 patients who underwent surgery for gastric cancer from March to May in 2010 at the Department of Surgery, Ruijin Hospital, Shanghai Jiao Tong University School of Medicine (Table 1). Grossly visible normal and cancerous portions of the specimens were snap-frozen in liquid nitrogen and stored at $-85^{\circ} \mathrm{C}$. None of the patients had received radiotherapy or chemotherapy prior to surgery.

Tissue specimens and microarray construction. A total of 161 patients who had curative surgery for gastric cancer at Ruijin Hospital, Shanghai Jiao Tong University School of Medicine from January 2002 to December 2003 were enrolled in the study. Patient-derived specimens were collected and archived under protocols approved by the Institutional Review Boards of Shanghai Jiao Tong University. The group was composed of 107 men and 54 women with a mean age of 57 (range 28-80) years at the time of operation. There were 63 cases at stage I, 39 at stage II, 46 at stage III, and 13 at stage IV. The diagnoses were confirmed by two pathologists, and the tumor grade and stage classifications were assigned according to the International Union Against Cancer guidelines [28]. None of the patients had received radiotherapy or chemotherapy prior to surgery, Patients with advanced gastric cancer received standard chemotherapeutic protocols, including 5-fluorouracil postoperatively, according to the NCCN Practice Guidelines for Gastric Cancer [29]. All patients were subjected to close follow-up observation. The follow-up deadline was October 2010.

For tissue microarray (TMA) construction, formalin-fixed, paraffin-embedded samples from above 161 patients that contained primary tumors and adjacent normal mucosa were retrieved from the archives of the Department of Pathology in Ruijin Hospital. Hematoxylin and eosin (H\&E)-stained slides were screened for tumor tissue and non-cancerous tissue adjacent to tumor (at least $2 \mathrm{~cm}$ from the tumor). Representative areas of tissue were established and 2.0-mm diameter cores were punched from the paraffin blocks. Two cores from each tumor and paired normal tissue (at least $2 \mathrm{~cm}$ from the tumor) were arrayed next to each other to ensure similar reaction conditions. All specimens were examined by two pathologists to prevent bias. Tumor and normal mucosa morphology on the arrays were validated as having high accordance with the whole archived section. TMA slides were constructed and made in collaboration with Shanghai Biochip (Shanghai, P. R. China).

Quantitative real-time PCR. Total RNA in 25 paired, frozen primary gastric cancer tissues, and adjacent normal mucosa were extracted according to the manufacturers instructions (Life Technologies, CA,USA, and then $0.5 \mu \mathrm{g}$ RNA was reverse transcribed into cDNA using a PrimerScript ${ }^{\mathrm{tm}} \mathrm{RT}$ reagent kit (Takara Bio Inc., Dalian, China). qPCR was performed in a $10 \mathrm{ml}$ total reaction mixture. Quantitative Hoxc6 mRNA levels were assessed by using ABI 7500 real-time PCR System (Applied Biosystems, Carlsbad, CA) with a Master Mix kit (Takara Bio Inc.,Dalian, China) according to the manufacturer's protocol. GAPDH was used as an internal control. 
Each Real-time PCR was repeated 3 times, 2- $\Delta \Delta$ Ct method was used for normalization with GAPDH as reference gene. Gene expression with a ratio of more than 2 was considered to be upregulated. The sequences for qRT-PCR primers were as follows:

GAPDH forward:TGTTGCCATCAATGACCCCTT

GAPDH reverse:CTCCACGACGTACTCAGCG

HOXC6 forward: CCCCACCAACTCTCCCCTAA

HOXC6 reverse:CAGGTCCACGTTTGACTCCC

Immunohistochemistry. The TMA sections were deparaffinized in xylene and rehydrated in graded series of ethanols followed by heat-induced epitope retrieval in citrate buffer ( $\mathrm{pH}$ 6.0). Hoxc6 expression were detected using a primary antibody against HOXC6 (Anti-Hoxc6 antibody produced in rabbit, Sigma.USA). After incubation with a biotinylated secondary antibody and DAB (Dako), the slides were rinsed and counterstained with Mayer's hematoxylin. Staining was scored by two independent investigators without knowledge of patient.outcomes according to the staining intensity and extent as described previously [30]. To evaluate Hoxc6 expression, immuostaining was classified into the following four groups according to both intensity and extent. The proportion of cells proteins expression was categorized as follows: $0,0 \%$ immunopositive cells; $1,<10 \%$ positive cells; $2,11 \sim 50 \%$ positive cells; $3,51 \sim 75 \%$ positive cells; and $4,>75 \%$ positive cells. The staining intensity was categorized by relative intensity as foll-ows: 0 , negative; 1 , weak; 3 , moderate; 4 , strong. The proportion and intensity scores were then multiplied to obtain a total score. To obtain final statistical results, scores less than 2 was considered as negative, while scores of $3 \sim 4$ were considered as $(+)$, scores of $5 \sim 8$ as (++), scores of $9 \sim 12$ as $(+++)$.

Statistical analysis. Statistical analysis was performed using SPSS 17.0 statistical software (Chicago, IL, USA) . Correlation was assessed with the Spearman rho correlation coefficient and Pearson chi-square test. Kaplan-Meier survival curves were generated and survival data were analyzed with the log-rank test. P values $<0.05$ were considered statistically significant.

Results. Up-regulation of Hoxc6 expression in primary gastric cancer tissues compared with adjacent normal mucosa. Of the 25 paired cases used for the evaluation of Hoxc6 mRNA, 16 (64\%) gastric cancer tissues showed at least a twofold increase in Hoxc6 mRNA level compared with the adjacent noncancerous mucosa (Figure1). The difference in Hoxc6 mRNA expression was significant $(64 \%$ vs $36 \% \mathrm{P}<0.05)$.

Association of Hoxc6 TMA immunohistochemical staining with patient clinicopathological parameters. Expression of Hoxc6 was predominantly localized in the nuclei and cytoplasm of tumor cells. Of the 161 TMA tumor specimens, Expression of Hoxc6 was observed in 76 (47.2\%) of tumors .Among them, 70 cases with a score of,+ 6 cases with a score of ++ respectively. Meanwhile, 29 of 161 (18\%) adjacent noncancerous tissues displayed positive staining, they could only be detected in adjacent dysplastic mucosa. Among them, 19 cases with a score of,+ 10 cases with a score of ++ respectively. The difference in Hoxc6 expression between tumor cells and

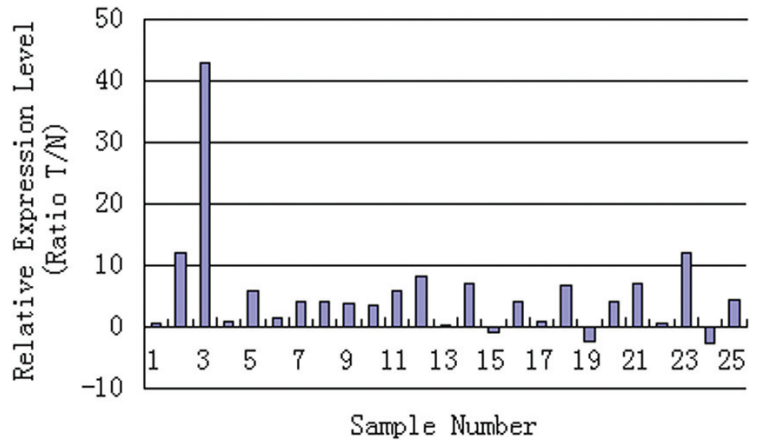

Figure 1. The Hoxc6 mRNA expression was significantly higher in the primary gastric carcinoma tissues.

Relative expression of Hoxc6 mRNA in fresh gastric cancer tissues comparing with normal tissues on qRT-PCR. All data are normalized using GAPDH as reference gene. The consistency of $q R T-P C R$ starting template requires that the $\mathrm{Ct}$-value be within 1. A normalized ratio of more than 2 on $\mathrm{Y}$-axis is determined to be gene expression upregulation, $\mathrm{X}$-axis refers to specimen number, The black actual line corresponds to a Y-value of 2 , showing the expression upregulation of Hoxc6 gene in 25 cases of gastric cancer samples .

adjacent noncancerous mucosa was significant( $47.2 \%$ vs $18 \%$ $\mathrm{P}<0.05$. Figure 2). Associations between clinicopathological factors and Hoxc6 expression are summarized (Table 2).

Table 2. The relationship of expression of Hoxc6 protein with clinic pathological parameters of gastric cancer

\begin{tabular}{|c|c|c|c|}
\hline & Negative & Positive & $\mathrm{P}$ (value) \\
\hline Gender & & & 0.316 \\
\hline Male & 53 & 54 & \\
\hline Female & 32 & 22 & \\
\hline Age (years old) & & & 0.558 \\
\hline$\leqq 60$ & 48 & 43 & \\
\hline$>60$ & 37 & 33 & \\
\hline Differentiation & & & 0.396 \\
\hline Poor & 61 & 49 & \\
\hline Well+Intermediate & 24 & 27 & \\
\hline Tumor Site & & & 0.94 \\
\hline Pylorus & 57 & 49 & \\
\hline Gastric Corpus & 22 & 21 & \\
\hline Gastric Fundus & 6 & 6 & \\
\hline Tumor Size (in Diameter) & & & 0.426 \\
\hline$\leqq 5 \mathrm{~cm}$ & 51 & 40 & \\
\hline$>5 \mathrm{~cm}$ & 34 & 36 & \\
\hline Depth of Invasion & & & $0.046^{*}$ \\
\hline Mucosa & 14 & 4 & \\
\hline Muscular Layer & 21 & 20 & \\
\hline Serosa & 50 & 52 & \\
\hline Lymph Node Status & & & 0.113 \\
\hline No & 41 & 27 & \\
\hline $\mathrm{N} 1-3$ & 44 & 49 & \\
\hline p-Stage & & & 0.103 \\
\hline $\mathrm{I}+\mathrm{II}$ & 59 & 43 & \\
\hline $\mathrm{III}+\mathrm{IV}$ & 26 & 33 & \\
\hline
\end{tabular}




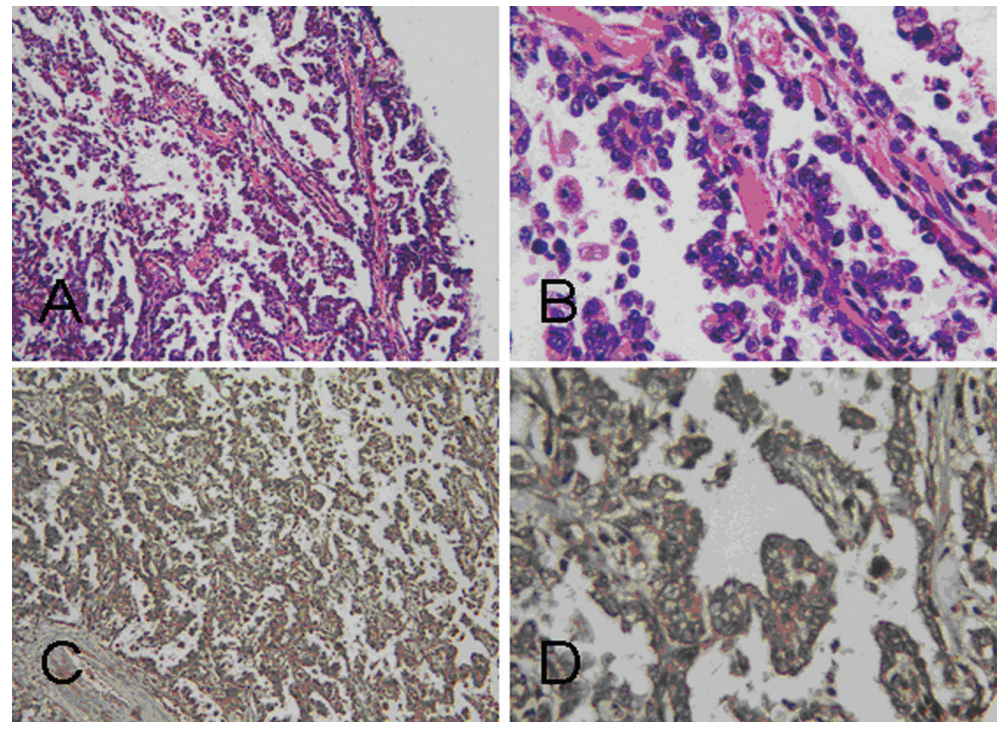

Figure 2A. The expression of Hoxc6 in primary gastric carcinoma papillary adenocarcinoma. $\mathrm{H}$-Estaining. $\mathrm{A} \times 100, \mathrm{~B} \times 400$. Immunostaing. $\mathrm{C} \times 100, \mathrm{D} \times 400$
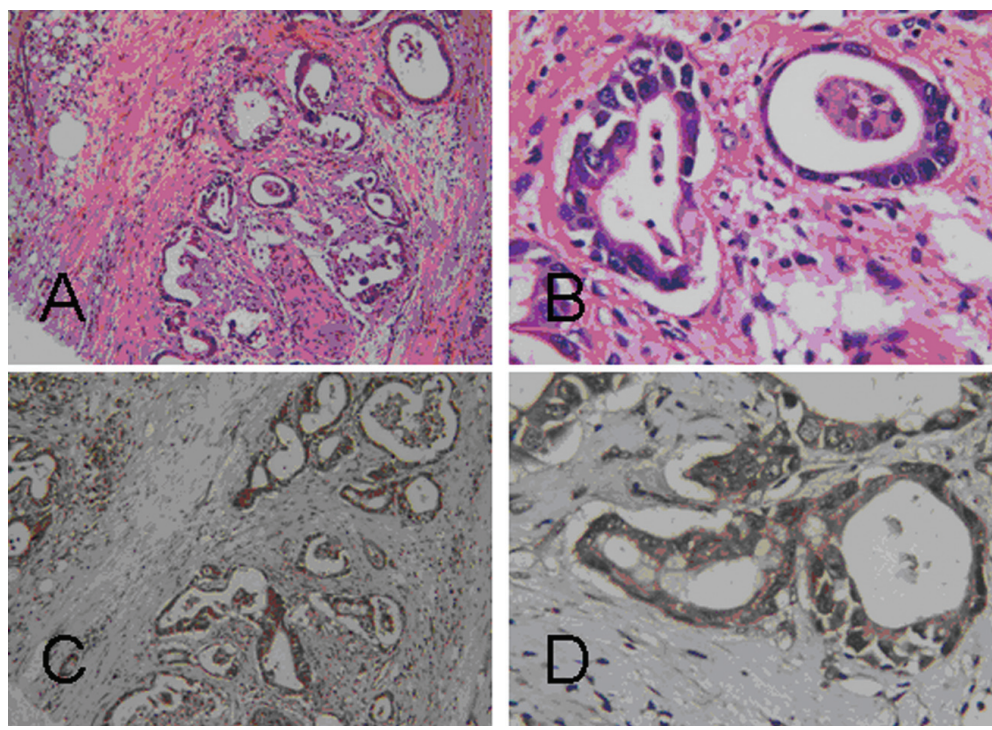

Figure 2B. The expression of Hoxc6 in primary gastric carcinoma well-differentiated tubular adenocarcinoma.

H-E staining. A $\times 100, B \times 400$. Immunostaing. $C \times 100, D \times 400$
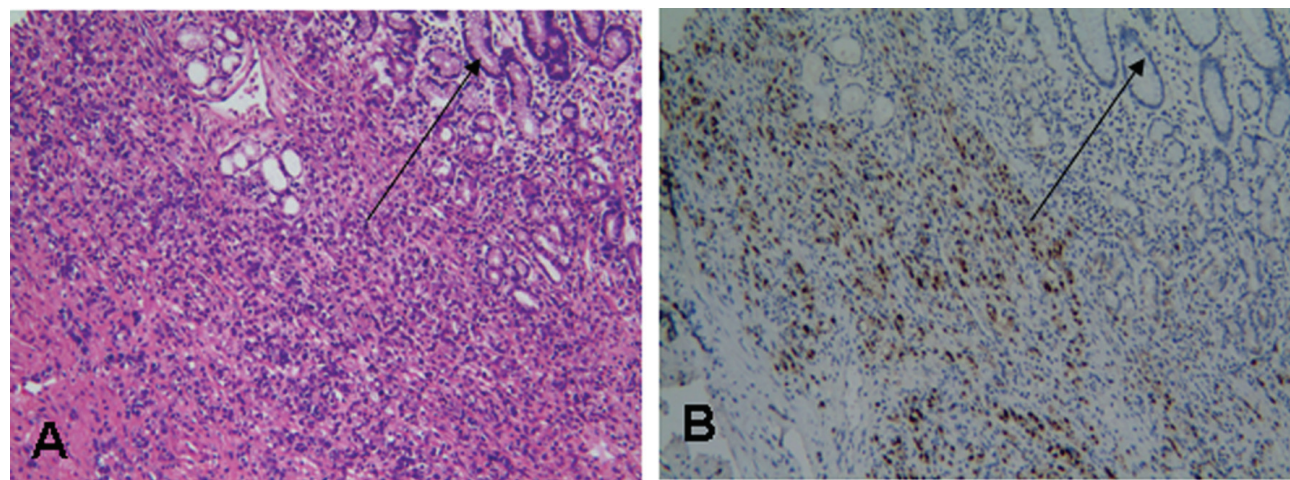

Figure 2C. Negative expression of Hoxc6 in normal gastric mucosa (Arrow).

H-E staining. A $\times 100$. Immunostaing. $B \times 100$ 
Increased Hoxc6 expression was significantly correlated with the depth of tumor invasion $(\mathrm{P}<0.05$. Table 2$)$.

Survival analysis and prognostic significance of Hoxc6 expression. Kaplan-Meier curves showed that patients with positive Hoxc6 expression had a lower overall survival rate than did the group with negative Hoxc6 expression $(\mathrm{P}<0.05$. Figure 3).

Discussion. It is evident that many of the molecular pathways that are involved in carcinogenesis represent aberrations of the normal processes that control embryogenesis. There are many examples in which the abnormal expression of genes that regulate growth and development have been involved in carcinogenesis. Among them the principal examples are Homeobox genes [1], Hox genes, a highly conserved subgroup of the homeobox superfamily, have crucial roles in development and differentiation. Aberrations in Hox gene expression have been reported in abnormal development and malignancy, therefore, Hox gene expression could be important in diagnosis and therapy in malignancy [31].

Normal Hox gene expression is disrupted and affects various pathways that promote tumorigenesis and metastasis. In some tumors, organogenesis pathways, such as receptor signalling pathways, are altered and drive tumor growth. At other times, Hox gene expression is altered and results in the maintenance of a more embryonic state through the activation of anti-apoptotic pathways or suppression of differentiation. Additionally, new mechanisms, such as protein-protein interactions, might also enable Hox proteins to maintain an oncogenic capacity [31].

Hoxc6 directly regulates expression of bone morphogenic protein 7 , fibroblast growth factor receptor 2, insulin-like growth factor binding protein 3 , and platelet-derived growth factor receptora ( PDGFRA) in prostate cells and indirectly influences the Notch and Wnt signaling pathways in vivo, inhibition of PD-GFRA reduces proliferation of prostate cancer cells, and that overexpression of Hoxc6 can overcome the effects of PDGFRA inhibition. Through above mechanisms, transcriptional network regulated by Hoxc6 plays crucial roles in proliferation, survival, and metastasis of prostate cancer cells [32]. In cultured human BON1 carcinoid cells, expression of Hoxc6 enhanced their proliferation, and knockdown of Hoxc6 inhibited their growth. Hoxc6 activated the oncogenic activator protein-1 signaling pathway through a physical interaction with JunD. Mutations in the homeodomain of Hoxc6 blocked this interaction and inhibited proliferation of carcinoid cells. Moreover, Hoxc6 induced the expression of genes that characteristically are up-regulated in carcinoid tumors, including neurotensin and connective tissue growth factor [33].

The aim of postoperative chemotherapy is to treat residual micrometastases after surgical resection to improve survival. Ideally, rational chemotherapy should be given to patients with high risk of recurrence and metastasis. However, it remains a great challenge to accurately predict outcome for each gastric cancer patient so that it will be easy to determine who will

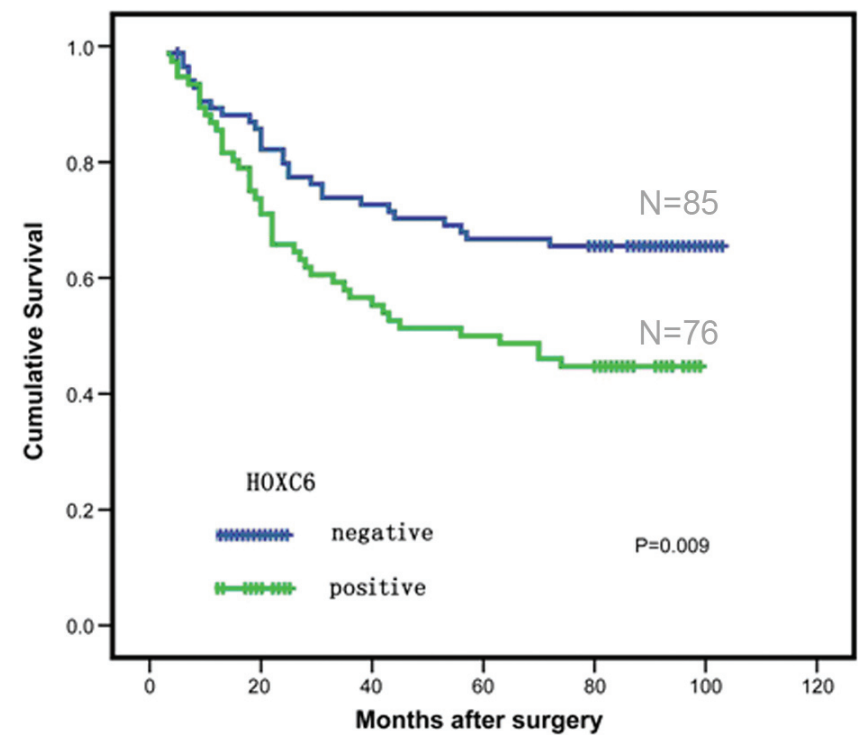

Figure 3. Univariate analysis of Hoxc6 expression with reference to overall survival $(\mathrm{P}<0.05)$.

Survival curve of patients with gastric cancer in regards to Hoxc6 expression. Patients with positive Hoxc6 expression had a lower overall survival rate than patients with negative expression $(P<0.05)$.

benefit from adjuvant therapy. Gastric cancer is highly heterogeneous, traditional prognostic factors such as TNM staging system is sometimes less predictive of outcome, particularly within the same stages of the disease, as a result, many patients receive unnecessary or insufficient adjuvant treatment which might be both harmful.

In our study, Hoxc6 protein was detected expressed in gastric cancer and dysplastic mucosal tissues, no Hoxc6 expression could be found in normal gastric mucosal cells. It is likely that Hoxc6 has been implicated in the pathogenesis of gastric cancer. The mechanism by which Hoxc6 involves in tumorigenesis remains to be investigated.

The expression of human Hoxc6 together with its correction of clinicopathological parameters in gastric epithelial neoplasms has not been reported before. In this study, we explored Hoxc6 gene mRNA and protein expressions in normal and malignant gastric tissues and we found Hoxc6 mRNA and protein had higher expression levels in cancer tissue than in its adjacent normal tissue, suggesting upregulation of Hoxc6 occurred at the transcriptional as well as posttranscriptional level. Our results showed that increased Hoxc6 expression was significantly correlated with the depth of tumor invasion, which hinted Hoxc6 expression may be associated with the development of gastric cancer. Our study also found that patients with positive Hoxc6 expression had a lower overall survival rate than did the group with negative Hoxc6 expression, so it would contribute to identify high risk patients who should receive more aggressive adjuvant chemotherapy, thus low risk patients receive less after potentially curative surgery. It also suggested that Hoxc6 could be a potential therapeutic 
target in the molecular pathways determining the behavior of gastric cancer.

These preliminary findings need to be verified in a larger, prospective, controlled clinical study, The mechanism by which Hoxc6 is involved in tumorigenesis and cancer progression has not been elucidated yet.

Acknowledgments: This study was supported by grants from National Natural Science Foundation of China (No. 81172324, No. 30900670), Science and Technology Commission of Shanghai Municipality (No. 10jc1411100, 09DZ1950100, and 09DZ2260200), Shanghai Key Discipline (S30204), and Key Projects in the National Science \& Technology Pillar Program of China (No. 2008BA152B03, and 2011BA203191)

\section{References}

[1] ABATE-SHEN C. Deregulated homeobox gene expression in cancer: cause or consequence? Nature Rev. Cancer 2002; 2: 777-785. http://dx.doi.org/10.1038/nrc907

[2] LAWRENCE HJ, STAGE KM., MATHEWS C. HW, DETMER K, SCIBIENSKI R, et al. Expression of HOX homeobox genes in lymphoid cells. Cell Growth Differ 1993; 4: 665-669.

[3] DEVITA G., BARBA P, ODARTCHENKI, N, GIVEL, J-C, FRESCHI G, et al. Expression of homeobox-containing genes in primary and metastatic colorectal cancer. Eur J Cancer 1993; 29: 887-893. http://dx.doi.org/10.1016/S09598049(05)80432-0

[4] CHARIOT A, CASTRONOVO V. Detection of HOXA1 expression in human breast cancer. Biochem. Biophys. Res 1996; 222: 292-297. http://dx.doi.org/10.1006/bbrc.1996.0737

[5] CILLO C, BARBA P, FRESCHI G, BUCCIARELLI G, MAGLI M.C et al. HOX gene expression in normal and neoplastic human kidney. Int J Cancer 1992; 51: 892-897. http://dx.doi. org/10.1002/ijc.2910510610

[6] CARE A, SILVANI A, MECCIA E, MATTIA G, STOPPACCIARO A et al. HOXB7 constitutively activates basic fibroblast growth factor in melanomas. Mol Cell Biol 1996; 16: 4842-4851.

[7] RIEGER E, BIJL JJ, VAN OOSTVEEN JW, SOYER HP, OUDEJANS CB et al. Expression of the homeobox gene HOXC4 in keratinocytes of normal skin and epithelial skin tumors is correlated with differentiation. J Investig Dermatol 1994; 103: 341-346. http://dx.doi.org/10.1111/1523-1747. $\underline{\text { ep12394888 }}$

[8] CALVO KR, SYKES DB, PASILLAS MP, KAMPS MP. Nup98HoxA9 immortalizes myeloid progenitors, enforces expression of Hoxa9, Hoxa7 and Meis1, and alters cytokine-specific responses in a manner similar to that induced by retroviral co-expression of Hoxa9 and Meis1. Oncogene 2002; 20 : 4247-56. http://dx.doi.org/10.1038/sj.onc. 1205516

[9] ZHANG X, HAMADA J, NISHIMOTO A, TAKAHASHI Y, MURAI T, et al. HOXC6 and HOXC11 increase transcription of S100beta gene in BrdU-induced in vitro differentiation of GOTO neuroblastoma cells into Schwannian cells. J Cell Mol Med 2007; 11: 299-306. http://dx.doi.org/10.1111/j.15824934.2007.00020.x
[10] CHEN H, ZHANG H, LEE J, LIANG X, WU X, et al. HOXA5 acts directly downstream of retinoic acid receptor beta and contributes to retinoic acid-induced apoptosis and growth inhibition. Cancer Res 2007; 67: 8007-13. http://dx.doi. org/10.1158/0008-5472.CAN-07-1405

[11] MIAO J, WANG Z, PROVENCHER H, MUIR B, DAHIYA $S$, et al. HOXB13 promotes ovarian cancer progression. Proc Natl Acad Sci U S A 2007; 104: 17093-8. http://dx.doi. org/10.1073/pnas.0707938104

[12] ZHAI Y, KUICK R, NAN B, OTA I, WEISS SJ, et al. Gene expression analysis of preinvasive and invasive cervical squamous cell carcinomas identifies HOXC10 as a key mediator of invasion. Cancer Res 2007; 67: 10163-72. http://dx.doi. org/10.1158/0008-5472.CAN-07-2056

[13] WU X, CHEN H, PARKER B, RUBIN E, ZHU T, et al. HOXB7, a homeodomain protein, is overexpressed in breast cancer and confers epithelial-mesenchymal transition. Cancer Res 2006; 66: 9527-34. http://dx.doi.org/10.1158/0008-5472.CAN-05$\underline{4470}$

[14] BODEY B, BODEY B JR, SIEGEL SE, LUCK JV, KAISER HE. Homeobox B3, B4, and C6 gene product expression in osteosarcomas as detected by immunocytochemistry. Anticancer Res 2000; 20: 2717-2721.

[15] BODEY B, BODEY B JR, SIEGEL SE, KAISER HE. Immunocytochemical detection of the homeobox B3, B4, and C6 gene products in childhood medulloblastomas/primitive neuroectodermal tumors. Anticancer Res 2000; 20: 1769-1780.

[16] BODEY B, BODEY B JR, SIEGEL SE, KAISER HE. Immunocytochemical detection of the homeobox B3, B4, and C6 gene products in breast carcinomas. Anti-cancer Res 2000; 20: 3281-3286.

[17] BODEY B, BODEY B JR, GRÖGER AM, SIEGEL SE, KAISER HE. Immunocytochemical detection of homeobox B3, B4, and C6 gene product expression in lung carcinomas. Anticancer Res 2000; 20: 2711-6.

[18] ERNST T, HERGENHAHN M, KENZELMANN M, COHEN CD, BONROUHI M, et al. Decrease and gain of gene expression are equally discriminatory markers for prostate carcinoma: a gene expression analysis on total and microdissected prostate tissue. Am J Pathol 2002; 160: 2169-2180. http://dx.doi.org/10.1016/S0002-9440(10)61165-0

[19] LEUNG WK, WU MS, KAKUGAWA Y, KIM JJ, YEOH KG, et al. Asia Pacific Working Group on Gastric Cancer. Screening for gastric cancer in Asia. current evidence and practice. Lancet Oncol 2008; 9: 279-87. http://dx.doi.org/10.1016/ $\underline{\mathrm{S} 1470-2045(08) 70072-X}$

[20] JEMAL A, SIEGEL R, XU J, WARD E. Cancer statistics. Cancer J Clin 2010; 60: 277-300. http://dx.doi.org/10.3322/ caac. 20073

[21] CUNNINGHAM D, OLIVEIRA J, ESMO Guidelines Working Group. Gastric cancer: ESMO clinical recommendations for diagnosis, treatment and follow-up.Ann Oncol 2008; 2: 23-4.

[22] DE MAAT MF, VAN DE VELDE CJ, UMETANI N, DE HEER P, PUTTER H, et al. Epigenetic silencing of cyclooxygenase-2 affects clinical outcome in gastric cancer. J Clin Oncol 2007; 25: 4887-94. http://dx.doi.org/10.1200/JCO.2006.09.8921 
[23] MACDONALD JS. Gastric cancer--new therapeutic options. N Engl J Med 2006; 355: 76-7. http://dx.doi.org/10.1056/ NEJMe068121

[24] HUNDAHL SA, WANEBO HJ. Changing gastric cancer treatment in the United States and the pursuit of quality. Eur J Surg Onco 2005; 31: 605-15. http://dx.doi.org/10.1016/ j.ejso.2005.02.011

[25] CREW KD, NEUGUT AI. Epidemiology of gastric cancer. World J Gastroenterol 2006; 12: 354-62.

[26] GRAVALOS C, JIMENO A. HER2 in gastric cancer: a new prognostic factor and a novel therapeutic target. Ann Oncol 2008; 19: 1523-9. http://dx.doi.org/10.1093/annonc/mdn169

[27] YANG S, CHUNG HC: Novel biomarker candidates for gastric cancer. Oncol Rep 2008; 19: 675-80.

[28] C WITTEKIND, LH SOBIN. TNM: Classification of Malignant Tumors 2002 - Wiley-Liss.

[29] AJANI J, D‘AMICO TA, HAYMAN JA, MEROPOL NJ, MINSKY B. National. Comprehensive Cancer Network.Gastric cancer. Clinical practice guidelines in Oncology. J Natl Compr Canc Netw 2003; 1: 28-39.

[30] XU C, ZHENG P, SHEN S, XU Y, WEI L, et al. NMR Structure and Regulated Expression in APL Cell of Human SH3BGRL3. FEBS Lett 2005; 579: 2788-94. http://dx.doi.org/10.1016/ j.febslet.2005.04.011

[31] SHAH N, SUKUMAR S: The Hox genes and their roles in oncogenesis. Nat Rev Cancer 2010; 10: 361-71. http://dx.doi. org/10.1038/nrc2826

[32] MCCABE CD, SPYROPOULOS DD, MARTIN D, MORENO CS. Genome-wide analysis of the homeobox C6 transcriptional network in prostate cancer. Cancer Res 2008; 68: 1988-96. http://dx.doi.org/10.1158/0008-5472.CAN-07-5843

[33] FUJIKI K, DUERR EM, KIKUCHI H, NG A, XAVIER $\mathrm{RJ}$, et al. Hoxc6 is overexpressed in gastrointestinal carcinoids and interacts with JunD to regulate tumor growth. Gastroenterology 2008; 135: 907-916. http://dx.doi.org/ $\underline{10.1053 / j . g a s t r o .2008 .06 .034}$ 